\title{
Everyday Tourism in a World Tourism City: Getting backstage in London
}

\author{
Robert Maitland \\ Professor of City Tourism, Faculty of Architecture and the Built Environment, \\ University of Westminster, 35 Marylebone Road, London NW1 5LS UK
}

r.a.maitland@westminster.ac.uk

\begin{abstract}
Tourism is increasingly important to city economies and the built environment is crucial to the tourist experience of cities. Accounts in the literature tend to focus on cities responding with planned development of iconic buildings and tourism precincts. Evidence from London and other world tourism cities shows that in many cases tourists want to explore the city beyond tourism precincts, and strive to get off the beaten track to discover the 'real city'. The architecture and built environment that is important to them is not iconic, monumental and planned, but the ordinary and everyday fabric of the city.
\end{abstract}

Keywords: City tourism; everyday; backstage; built environment

eISSN: 2398-4295 @ 2016. The Authors. Published for AMER ABRA by e-International Publishing House, Ltd., UK.. This is an open access article under the CC BY-NC-ND license (http://creativecommons.org/licenses/by-nc-nd/4.0/). Peer-review under responsibility of AMER (Association of Malaysian Environment-Behaviour Researchers), ABRA (Association of Behavioural Researchers on Asians) and CE-Bs (Centre for Environment-Behaviour Studies), Faculty of Architecture, Planning \& Surveying, Universiti Teknologi MARA, Malaysia.

https://doi.org/10.21834/ajbes.v1i1.16 


\subsection{Introduction}

The growing importance of tourism to city economies is widely recognised and the built environment is crucial to the tourist experience of cities. However the literature on tourism development has emphasised cities responding by constructing iconic buildings and planned tourism precincts or zones. This paper uses evidence from London and other world tourism cities to argue that in many cases tourists want to explore the city beyond tourism precincts and strive to get off the beaten track and discover the 'real city'. The architecture and built environment that is important to them is not iconic, monumental and planned, but the ordinary and everyday fabric of the city.

\subsection{Literature Review}

Globalisation and profound economic change have transformed cities over the past decades, and tourism has been an inseparable part of that process. It has become an indispensible element in urban economies and image making, and as 'entrepreneurial cities' (Harvey 1989) have sought to develop tourism and represent themselves as leading players on the world stage, they have mined their heritage and built environment assets, reconfigured places, invested in 'iconic' architecture and repackaged their culture. This process has been at work in former industrial cities such as Baltimore, USA or Lille, France, but has also affected more established tourist historic cities and the growing tourist cities of East Asia. It has been perhaps particularly notable in polycentric 'world tourism cities' (Maitland and Newman, 2009) that are global nodes and well known tourism destinations - London, Berlin or Sydney, for example.

Revalorising cities for tourism and events has brought success to some cities. Yet paradoxically, the search for differentiation has led to serial reproduction of 'placeless' environments that might be anywhere. Perhaps inevitably, the response has been to redouble efforts to reconfigure the city's built environment and culture to create distinctiveness, through for example cultural quarters; promoting 'creative spaces' (Evans 2007); and iconic buildings. Cities and tourism managers see copying good ideas as a safe strategy (Richards and Wilson 2006). But the result is a homogenised environment that reduces cities' attractiveness to increasingly sophisticated tourists.

Conventionally, tourism has been seen as a separate activity, and tourists as a separate group with particular demands and interests that differ from those of city residents. Globalisation and the rise of a mobile global middle class have changed that. Leisure tourism is now just one of many different mobilities that bring people to cities. There are other less visible tourists in cities - business visitors, educational and health tourists, people visiting friends and relations - and there are other mobilities. Migrations are increasing: mobile professionals move between cities as company assignments change; students move between countries and cities to complete their education; permanent or short term migrants move in search of jobs. As the difference between tourism and other mobilities blurs, so does the difference between touristic and non-touristic behaviours. Cities are centres for entertainment and cultural consumption, and residents' consumption demands have been changed by their own experience as tourists: citizens have learned to 'act like tourists in their own cities' (Lloyd 2000:7) in their behaviours and consumption demands. Tourism has become pervasive, inextricably part of the life of the city. It is no longer a separate activity, confined to particular 
areas or to particular times (Franklin and Crang 2001).There has been a de-differentiation between 'touristic' and 'non-touristic' behaviour, and between 'tourists' and 'locals'.

In a world tourist city like London, tourists are frequently experienced travellers. They are sophisticated consumers of the city who defy conventional tourist stereotypes and want to 'fit in rather than stand out' (Maitland and Newman 2009: 135). And many city residents, though not classified as tourists, are relative newcomers who will not stay long - students are an obvious example. Like tourists, they want to explore the city during their time there. Yet long-standing city residents of the global middle class have a cosmopolitan orientation and consciously identify themselves not as local but as global citizens (Rofe 2003). They behave in a touristic manner, consuming the city 'as if' tourists (Clark 2003). In short, people no longer conform to traditional roles. This 'reciprocal transgression' emphasises the de-differentiation between tourists and residents, and touristic and non-touristic spaces in the city (Franklin 2003). Many visitors are now experienced users of cities who want to move beyond traditional tourism precincts; in London more than $60 \%$ of overseas tourists have visited the city before, often many times.

\subsection{Methodology}

A distinction has long been made between front stage areas, presented for tourism, and back stage areas, where 'real life' goes on. Pearce and Moscardo (1986) identified six gradations between front and back stage and sophisticated city users may avoid commodified areas and seek places that are, at least to some degree, back stage. This process of city exploration can be particularly rewarding in world tourism cities; their multiple social, physical and economic assets and polycentric spatial structures open up opportunities for tourism to develop away from traditional zones and for visitors to discover places off the beaten track.

The Centre for Tourism Research at the University of Westminster pioneered work on how tourists get off the beaten track in world tourism cities. We take a broad view of what constitutes a tourist, consistent with the earlier discussion and include day visitors, internal tourists, temporary residents as well as domestic and overseas visitors in our work. We have used questionnaire surveys, but predominantly interviews and other qualitative techniques to examine the appeal of areas that are not part of traditional tourist itineraries nor planned as tourist bubbles, cultural quarters or tourism precincts. This has encompassed work in various areas of London - in Bankside and Islington (for example, Maitland and Newman 2004; Maitland 2008; Maitland 2010), and Spitalfields, (Pappalepore, Maitland and Smith 2010), Hoxton, London Fields and Deptford - and in five world tourism cities: Berlin, London, New York, Paris, and Sydney (Maitland and Newman 2009).

The focus here is on research undertaken between 2002-2010 in Islington, Bankside, and Spitalfields - places in inner London once dominated by manufacturing, wholesale or dock related industries and working class housing that have been moving upscale. They are at different stages of gentrification. Islington has long experienced gentrification and can now be seen as a 'global space serving the international service class diaspora in a safe environment that acknowledges the cultural capital of the consumer' (Butler 2007:184). Bankside includes two popular attractions (Shakespeare's Globe and Tate Modern) and is becoming a wellrecognised destination; our research was at an earlier stage in its development, and tourism was just one element in a process that encompassed real estate development and 
infrastructural improvements. Spitalfields is well away from the main tourist core. It includes creative businesses, independent shops and a buoyant night-time economy; Bengali restaurants around Brick Lane are part of its attraction. Though gradually integrating into London's mainstream tourism offer, for most visitors these areas remain off the beaten track, not seen as tourism zones.

\subsection{Results and Discussions}

The appeal of these areas is discussed below; quotations from interviewees are shown in italics.

\subsection{The appeal of the uncontrived}

Architecture and street patterns proved important to all interviewees, but had different significance. For a minority, the built environment was an agreeable backdrop as they consumed the areas. Islington was a pleasant environment a lot cleaner, nice and tidier than Clapham or sort of down that way, so the area also felt safe. Tourists enjoyed Bankside as a nice place and the built environment enhanced the experience, but in ways interviewees struggled to define: we like the buildings ...the way the buildings are built ... the style in which the buildings have been made. That is not to denigrate these people's experiences; they liked the area, and enjoyed their surroundings but did not identify what they liked with any precision. This suggests that being off the beaten track was not important to them. Rather, they enjoyed an area that was well looked after and provided buildings and a morphology that matched their expectations. It seems likely that a planned tourist area - like a tourist bubble or cultural quarter - would have elicited a similarly positive reaction.

Yet most visitors articulated the areas' appeal much more precisely. They frequently evoked atmosphere as crucial to their enjoyment. This encompassed a threefold combination: built environment that did not seem to have been commodified for visitors - and so was contrasted with other areas seen as in a way, too clean; a mix of people in which tourists did not seem dominant - so places where there aren't so many people catering for tourists: and distinctive features like independent shops or cool bars, contrasted with the kind of pub and discothèque you can find everywhere.

Elements of the built environment were discussed in detail. In Islington general appraisal was backed by detail: I really liked the windows of those shops, how they are designed, how they do it. In Bankside too, there were detailed architectural assessments - This part of the city, well, they're doing construction to make it more modern but.. older buildings ... they're just trying to upkeep the brick and the whatnot from a lot of years ago which is nice. Tourists felt reciprocity between buildings and people. The built environment could be seen as a text to be read, a way to learn about the city - yet some interviewees seemed to engage more actively with the city. Physical qualities of place were seen as embedding both history and the contemporary nature of the city - there is a mix ... it's multicultural... a mix of people ... so in the culture there should be the old part and the new part of London. In Spitalfields, overseas visitors spoke of the way old buildings had been re-used: for us it is very interesting because it is like the new London tries to accept the ancient London, in a way we assimilate our past but doing new things. 
Visitors felt themselves to be in places that were uncontrived, not reconfigured for tourist consumption and therefore a part of the 'real city'. This arose from a contrast to well known tourist hotspots - not like the Champs Elysée [where] you feel there are only tourists - and from their seeming rooted in the genius loci of the city, rather than being standardised and reproducible. As one interviewee said, discussing the appeal of an area without iconic attractions: museums are museums, and they're all interesting but museums are anywhere and I like to see more what the city is actually about ... you get to know a city more by seeing the little not so touristy things.

\subsection{The allure of the ordinary}

Visitors are alert to signs of a reconfigured tourist zone - and equally to signifiers of the 'real city', the city of everyday life. The presence of local people is a key marker and signifier: tourist spots are always very generic, right, look at the places where tourist are in any city you feel like, oh, I'm just one of the them and I'm just doing the typical tourist thing but if you, somehow, end up in the place where the locals go, it feels like a more authentic experience.

In these real places, the routines and rhythms of everyday life take on a new significance. Mundane daily routines of shopping, going for a coffee, being at work give meaning to places not dominated by a show put on for visitors: it doesn't feel artificial... you don't feel like you're in Disneyland. Respondents frequently returned to the significance of the everyday and ordinary routines. Local people can be both a marker of the authentic and a taste of the exotic. I see people who live near this area, they know each other when they see other people in the street, and I think that's why it's real London. Interaction with local people was important: it's more authentic and fun, because local people and tourists, they also mix. Here, you are not treated as a tourist. Indeed, people are more relaxed, and you are not treated as a nobody, they have a little conversation with you. More than that, mundane quotidian routines become a source of fascination. Visitors commented enthusiastically about the pleasure of see[ing] people going about their tasks, observing ordinary Londoners just doing their thing, and people going about their day, as they would. Everyday work routines take on new significance - a glimpse of an office worker at their computer, seen through a window, seems really cool, as part of the real London. Going to the local supermarket feels like an incredible experience, since one can observe local people and what they choose to consume: one of our favourite places has been Tesco ... we just like to look around and see. The tourist gaze of the outsider creates the exotic from ordinary life: the everyday is not simply ordinary - 'rather it is the site that contains the extraordinary within the ordinary if one is prepared to look'. (Till (2009: 139, emphasis added).

\subsection{Reimagining the city}

Everyone brings their own imaginaries to a destination, and world cities like London encourage a rich range of imaginaries, from induced and organic sources. But imaginaries are not immutable. Wynn (2010) describes how guides offering walking tours in New York construct new meanings from the city's resources of culture, history and spaces: 'actors like tour guides take everyday fragments, perhaps even the ephemera that have been left in the dustbins of history, and transform them into something new ... [that] shape interactions in public space' ( $p 150)$

He calls this urban alchemy - a process that transforms the material of everyday experience into something else - that 're-enchants' the city and creates 'mutual attachment between the 
city and the tourists (p150). In his account, the alchemists are guides, but it seems that tourists can also be alchemists. Wandering around is central to experiencing places; it takes you like kind of off the beaten path. It is used as a way to discover places; I just walk and [decide what to do] at the moment. Visitors create their own tours as they walk and ... every time I find different things or walk and think. I get lost and look for the way back. In doing so they can draw on the city's everyday qualities - place, residents, co-tourists - to create their own narratives and imaginaries. This is much more likely in off the beaten track areas that have not been deliberately designed for visitors and which do not already carry strong historical or cultural narratives. It is in ordinary places that 'everyday folk can create a kind of magical urbanism' (Wynn, 2010:147).

Yet a paradox emerging from the research is that whilst interviewees frequently refer to the 'real city', they also know that the areas they are visiting are in many ways atypical. They realize that Islington is largely gentrified and expensive, supporting a range of high-end consumption opportunities for the well off - yuppies, maybe, and that to live in Bankside you've got to be rich ... more than rich. They recognize Spitalfields as the fashionable part of town. $A$ resolution to the paradox is that for visitors 'real' in some ways means ideal: they enjoy the areas precisely because they are somewhat unrepresentative of much of the modern commercial city. An intimate morphology, a villagey feel, independent shops selling choice items, craftspeople selling their wares in markets all hark back to a disappearing past. This, and the opportunity for interaction with locals and other co-tourists and to observe everyday life can be seen as an attempt to recover an (idealised) past as an act of resistance (Vivant 2010) to today's sanitized, homogenised and alienating cityscape, deliberately constructed and planned by commercial forces. As Davies (1979) points out, nostalgia can be read as resistance to contemporary capitalism and urban form.

\subsection{Conclusion}

Contemporary visitors to cities are not the dumb tourists of popular stereotype. Touristic behaviours are performed by a range of city users, who are in the city for varying lengths of time, and have varying knowledge and attachment. Differences between tourists and residents, touristic and non-touristic practices are increasingly blurred. The built environment is at the heart of how cities have adapted themselves to encourage tourism, but whilst sometimes visitors do want to experience the city as monumental spectacle and set of iconic attractions, often they seek places that are distinctive and uncontrived, not planned as tourism zones. As they try to get backstage, engagement with the built environment is crucial to their search for the real city. Yet the 'real city' is a complex concept with different though interconnected meanings. It can be found in:

- $\quad$ areas that are distinctive, hard to reproduce, rooted in the city's history and culture as reflected in its buildings and spaces.

- $\quad$ the opportunity to experience everyday life - where those who are prepared to look can find the extraordinary

- $\quad$ a reimagined city, in which tourists perform urban alchemy to construct their own narratives of place, perhaps in resistance to the homogenising forces reshaping cities. Iconic architecture, costly new attractions and reconfigured tourism zones have limited appeal. Tourists' demands are subtler than may be thought, and heterogeneous areas off the 
beaten track can provide satisfying experiences for a wide range of city users, with opportunities for conviviality and for creating ones own narrative of place. Policy and urban design should shift away from serial reproduction of standardised touristscapes, and focus on more delicate and limited interventions that help areas develop in the ways that tourists and other city users enjoy.

\section{Acknowledgement}

This paper draws on research and ideas carried out and developed with Dr llaria Pappalepore, Professor Peter Newman and Dr Andrew Smith, University of Westminster.

\section{References}

Butler, T (2007). Gentrification. In Buck, N., Gordon, I., Ahrding, A., and Turok, I., Changing Cities. Basingstoke: Palgrave, 172-187.

Davies F (1979). Yearning for yesterday: a sociology of nostalgia. New York: Free Press.

Fainstein S, and Judd D (eds). Yale University Press: New Haven; 21-34

Franklin, A. (2003). Tourism. An Introduction. London: Sage.

Franklin, A. and M. Crang (2001). Trouble with Tourism and Travel Theory? Tourist Studies, 1(1), 5-22.

Harvey D. (1989). The condition of postmodernity, Oxford: Basil Blackwell.

Jalaladdini S and Oktay D (2013). Interrogating Vitality in the Streets of Two Cyprus Towns. ajE-Bs, 4(11), 63-74.

Judd, D. (2003). Urban tourism and the geography of the city. EURE, 29(87), 51.

Lloyd, R. (2000). Grit as Glamour. cited in D. Judd 2003. Visitors and the Spatial Ecology of the City, in L Hoffman, S Fainstein, D Judd eds. Cities and Visitors Blackwell. Oxford: 23-38.

Maitland, R. and Newman, P. (2004). Developing metropolitan tourism on the fringe of central London'. International Journal of Tourism Research, 6, 339-348.

Maitland, R. (2008). Conviviality and Everyday Life: the Appeal of New Areas of London for Visitors. International Journal of Tourism Research, 10(1), 15-25.

Maitland, R. (2010). Everyday life as a creative experience in cities. International Journal of Culture, Tourism and Hospitality Research. 4, 3.

Maitland, R. and Newman, P. (2009). World Tourism Cities: developing tourism off the beaten track. Abingdon: Routledge.

Pappalepore, I., Maitland, R., and Smith, A. (2011). Exploring urban creativity: visitor experiences of Spitalfields, London. Tourism, Culture \& Communication, 10.

Pearce, P. and Moscardo, G. (1986). The Concept of Authenticity in Tourist Experiences. ANZJS, 22(10), 121-132. Richards, G \& Wilson, J. (2007). Tourism development trajectories: from culture to creativity? In G. Richards \& J. Wilson (Eds) Tourism, Creativity and Development, pp.1-34. New York: Routledge 
Maitland, R. / Asian Journal Of Behavioural Studies, AjBeS, Maiden, 1(1), May/June 2016 (p.13-20).

Rofe M. (2003). I Want to be Global: Theorising the gentrifying class as an emergent elite global community. Urban Studies, 40(12), 2512-2526.

Teedon P. (2001). Designing a place called Bankside. European Planning Studies, 9(4), 459-481

Till, J. (2009). Architecture Depends. Cambridge, Mass, MIT Press.

Vivant E (2010). The (re)Making of Paris as a Bohemian Place? Progress Planning, 74, 107-152.

Wynn, J. (2010). City Tour Guides: Urban Alchemists at Work. City and Community, 9(2), 145-163. 